\title{
PENGARUH PEMBERIAN PUPUK NPK GROWER DAN DEFOLIASI TERHADAP PERKEMBANGAN BIJI DAN PRODUKSITANAMAN JAGUNG (Zea mays L.)
}

\section{The Effect of NPK Grower Fertilizer and Defoliation on Seed Development and Production of Corn Plants (Zea mays L.)}

\author{
Prihatin Ponco Pamungkas, Maizar, Sulhaswardi \\ Program Studi Agroteknologi, Fakultas Pertanian Universitas Islam Riau \\ Jl Kaharudin Nasution No.113 Pekanbaru. 28284 \\ Telp: 0761-674681; Fax: 0761-674681 \\ [Diterima: Oktober 2017; Disetujui: Desember 2017]
}

\begin{abstract}
The study aimed to determine the effect of giving NPK Grower fertilizer and defoliation to seed development and corn crop production. The design used in this study was a Factorial Completely Randomized Design consisting of two factors. The first factor is NPK Grower (N) fertilizer with a dose of $0,7.5,15,22.5 \mathrm{~g} /$ plant while the second factor is Defoliation (D) with some $0,2,4$, all leaves under the cob. The parameters observed were changes in seed dry weight $(\mathrm{g})$, changes in seed moisture content (\%), speed of accumulation of dry matter ( $\mathrm{mg} / \mathrm{seeds} /$ day), effective filling time (days), harvest age (days), and dry shelled weight ( $\mathrm{g}$ ). The last observation data were analyzed statistically and continued with a BNJ follow-up test at the level of 5\%. The results showed that interactively giving NPK Grower and Defoliation fertilizer had a significant effect on changes in seed dry weight, changes in seed moisture content, speed of dry matter accumulation, harvest age and dry shell weight. The best treatment is in the combination of $22.5 \mathrm{~g} /$ plant NPK Grower fertilizer treatment and Defoliation of all leaves under the cob (N3D3). The main effect of NPK Grower fertilizer has a significant effect on all parameters. The best treatment for NPK Grower fertilizer is $22.5 \mathrm{~g} /$ plant (N3). The main effect of Defoliation has a significant effect on all parameters. Best treatment Defoliate all leaves under the cob (D3).
\end{abstract}

Keywords: Corn, NPK Grower Fertilizer, Defoliate

\begin{abstract}
ABSTRAK
Tujuan penelitian untuk mengetahui Pengaruh Pemberian Pupuk NPK Growerdan Defoliasi Terhadap Perkembangan Biji dan Produksi Tanaman Jagung. Rancangan yang digunakan dalam penelitian ini adalah Rancangan Acak Lengkap Faktorial yang terdiri dari dua faktor. Faktor pertama adalah pupuk NPK Grower (N) dengan dosis 0,7,5, 15, 22,5 g/tanaman sedangkan faktor kedua yaitu Defoliasi (D) dengan jumlah 0, 2, 4, semua daun di bawah tongkol. Parameter yang diamati adalah perubahan berat kering biji (g), perubahan kadar air biji (\%), kecepatan penumpukan bahan kering (mg/biji/hari), waktu pengisian efektif (hari), umur panen (hari), dan berat pipilan kering ( $\mathrm{g}$ ). Data pengamatan terakhir dianalisis secara statistik dan dilanjutkan dengan uji lanjut BNJ pada taraf 5\%.Hasil penelitian menunjukkan bahwa secara interaksi pemberian pupuk NPK Grower dan Defoliasi memberikan pengaruh nyata terhadap perubahan berat kering biji, perubahan kadar air biji, kecepatan penumpukan bahan kering, umur panen dan berat pipilan kering. Perlakuan terbaik terdapat pada kombinasi perlakuan pupuk NPK Grower 22,5 g/tanaman dan Defoliasi semua daun di bawah tongkol (N3D3).Pengaruh utama pupuk NPK Grower berpengaruh nyata terhadap semua parameter. Perlakuan terbaik pupuk NPK Grower 22,5 g/tanaman (N3).Pengaruh utama Defoliasi berpengaruh nyata terhadap semua parameter.Perlakuan terbaik Defoliasi semua daun di bawah tongkol (D3).
\end{abstract}

Kata Kunci:Jagung, Pupuk NPK Grower, Defoliasi. 


\section{PENDAHULUAN}

Tanaman jagung (Zea mays L) adalah salah satu jenis tanaman serealia yang sangat populer di Indonesia, sebagai sumber pemenuh kebutuhan karbohidrat dan juga sebagai pemenuh kebutuhan kalori tubuh.Jagung juga merupakan salah satu komoditas utama pertanian sebagai bahan pangan penting selain padi.Berdasarkan urutan bahan makanan pokok dunia, jagung menduduki urutan ketiga setelah gandum dan padi.Sedangkan di Indonesia jagung merupakan makanan pokok kedua setelah padi (Anonimus, 1995).

Dewasa ini jagung tidak hanya untuk pangan tetapi juga merupakan bahan dasar atau bahan olahan untuk minyak goreng, tepung maizena, ethanol, asam organik, makanan kecil, dan sebagian besar dimanfaatkan untuk pakan ternak, terutama unggas, sehingga impor jagung harus dilakukan, oleh karena itu produksi jagung di dalam negri perlu terus ditingkatkan, baik melalui program intensifikasi maupun ekstensifikasi (Anonimus, 2002).

Anonimus (2016), menyatakan bahwa impor jagung pada tahun 2015 sebesar 1,7 juta ton. Namun pada bulan Juni 2016 angka impor jagung baru dikisarkan 800.000 ton. Sementara itu, berdasarkan data Badan Penelitian dan Pengembangan Pertanian Kementrian Pertanian (Balitbangtan) target produksi jagung nasional pada 2016 adalah 21,35 juta ton, sementara kebutuhan jagung Indonesia sekitar 23,4 juta ton per tahun. Maka dari itu, pemerintah masih harus mengimpor jagung untuk memenuhi selisih angka target produksi dengan kebutuhan tersebut.

Untuk mengatasi hal tersebut maka perlu ditingkatkan produktivitas tanaman jagung tersebut dengan teknik budidaya yang baik dan sesuai untuk menutupi kekurangan jagung sehingga pemerintah tidak perlu mengimpor jagung dari luar negeri. Upaya-upaya yang dapat dilakukan antara lain dengan penggunaan varietas unggul, pemangkasan daun (defoliasi), dan pemupukan yang sesuai.

Meskipun jagung mudah tumbuh di berbagai jenis tanah, namun tingkat kesuburan tanah juga menentukan pertumbuhan dan produksi dari jagung tersebut. Menurut Rukmana (1997), tanaman jagung untuk dapat tumbuh dan berproduksi secara optimal memerlukan cukup hara utamanya nitrogen $(\mathrm{N})$, fospat (P), dan kalium (K). Jagung membutuhkan pupuk nitrogen terbanyak setelah padi. Beberapa hasil penelitian menunjukkan bahwa tanpa pemberian pupuk nitrogen $(\mathrm{N})$, tanaman jagung tidak akan mendapatkan hasil sesuai yang diharapkan.

Salah satu cara untuk melakukan pemeliharaan tanah ialah menjamin tanah tetap subur dalam arti cukup mengandung zat-zat mineral. Untuk menjamin kesuburan pada tanah dilakukan pemupukan dengan pemberian pupuk NPK Grower.Pupuk NPK Grower merupakan pupuk jenis baru yang memiliki kandungan hara hara makro dan mikro sekaligus dalam setiap butirnya.

Pupuk NPK Grower dapat mempengaruhi pertumbuhan vegetatif dan generatif tanaman salah satunya ialah umur panen tanaman, karena NPK Grower merupakan salah satu jenis pupuk majemuk yang mengandung unsur hara $15 \%$ nitrogen $(\mathrm{N})$, 9\% fospat (P), 20\% kalium (K), dan beberapa unsur hara mikro lainnya yang sangat dibutuhkan tanaman walaupun yang diperlukan hanya dalam jumlah yang relatif sedikit, (Anonimus, 2003).

Menurut Ismail, Saefuddin dan Zulfica dalam Razali (2008), jagung juga dipengaruhi oleh faktor internal seperti daun, yang mempunyai peranan penting dalam penyerapan cahaya matahari sebagai sumber utama energi dalam proses fotosintesis. Asimilat yang diproduksi oleh daun akan didistribusikan pada fase vegetatif aktif, akan merata keseluruh jaringan tanaman. Sedangkan pada saat fase generatif berlangsung maka sebagian besar hasil asimilasi akan ditranslokasikan ke bagian jaringan penyimpanan sehingga dapat menyebabkan terjadinya persaingan antara bagian vegetatif maupun bagian generatif tanaman, terutama dalam memanfaatkan hasilhasil asimilasi dari sumber ke bagian sink atau pengguna.

Defoliasi adalah pemotongan atau pengambilan bagian tanaman yang ada diatas permukaan tanah. Perlakuan defoliasi merupakan salah satu upaya untuk mengurangi persaingan internal hasil asimilasi dan memaksimalkan asimilat yang akan 
ditranslokasikan ke biji. Perlakuan Defoliasi pada daun bagian bawah diharapkan mampu meningkatkan laju fotosintesis pada daun-daun bagian atas atau daun muda, sehingga akumulasi hasil dari proses fotosintesis untuk pengisian biji dapat lebih optimal (Ismail, Saefuddin dan Zulfica dalam Razali, 2008).

Slatyer dalam Bustamam (2004), mengungkapkan bahwa hasil fotosintesis pada tanaman jagung yang diakumulasikan setelah pembungaan mempunyai kontribusi yang sangat besar dalam pengisian biji dibandingkan dengan akumulasi hasil fotosintesis sebelum pembungaan. Selanjutnya diungkapkan oleh Johnson dalam Bustamam (2004), bahwa pemangkasan daun jagung pada stadia vegetatif dapat menyebabkan penurunan hasil karena pemangkasan daun tersebut akan menyebabkan pengurangan tinggi tanaman serta luas permukaan daun yang menjadi media proses fostosintesis.

Pupuk NPK Grower diharapkan akan mampu memenuhi kebutuhan unsur hara pada tanaman jagung, baik berupa unsur hara makro maupun unsur hara mikro. Sedangkan Defoliasi diharapkan mampu mempercepat perkembangan tongkol dan meminimalisasi kehilangan air pada tanaman jagung. Dari perpaduan keduanya diharapkan akan mampu meningkatkan proses pertumbuhan vegetatif dan generatif tanaman jagung, yang akan memberikan hasil panen yang lebih maksimal dan kualitas buah yang lebih baik.

Dari permasalahan di atas penulis telah melakukan penelitian dengan judul: "Pengaruh Pemberian Pupuk NPK Grower dan Defoliasi terhadap Perkembangan Biji dan Produksi Tanaman Jagung (Zea mays L)".

\section{BAHAN DAN METODE}

Penelitian ini telah dilaksanakan di kebun percobaan Fakultas Pertanian Universitas Islam Riau, Jalan Kaharuddin Nasution KM 11 No. 113 Perhentian Marpoyan, Kelurahan Air Dingin, Kecamatan Bukit Raya, Pekanbaru. Penelitian ini telah dilaksanakan selama lima bulan terhitung dari bulan Maret sampai dengan bulan Juli 2017.

Bahan-bahan yang telah digunakan dalam penelitian ini adalah benih jagung hibrida varietas BISI-2, pupuk NPK Grower, insektisida Decis, fungisida Dithane M-45, Curater 3G, tali raffia, paku, kayu, plat seng, cat minyak dan kuas. Sedangkan alat-alat yang telah digunakan dalam penelitian ini adalah traktor, cangkul, garu, parang, martil, penggaris, meteran, gembor, handsprayer, knapsack 161 , gunting, pisau karter, pinset, karet gelang, plastik bening, kertas HVS, jangka sorong, timbangan analitik, oven, kamera dan alat tulis.

Penelitian ini menggunakan Rancangan Acak Lengkap (RAL) Faktorial 4x4 yang terdiri dari 2 faktor yaitu faktor pupuk NPK Grower (N) dengan 4 taraf perlakuan dan faktor Defoliasi (D) dengan 4 taraf perlakuan sehingga diperoleh 16 kombinasi perlakuan. Dimana setiap perlakuan terdiri dari 3 ulangan sehingga diperoleh 48 satuan percobaan (plot).Setiap satuan percobaan (plot) terdiri dari 4 tanaman dan 2 diantaranya dijadikan sebagai tanaman sampel, sehingga didapat 192 tanaman.

Parameter yang diamati adalah perubahan berat kering biji, perubahan kadar air biji, kecepatan penumpukan bahan kering, waktu pengisian efektif, umur panen, panjang tongkol, diameter tongkol dan berat pipilan kering.

\section{HASIL DAN PEMBAHASAAN}

\section{Perubahan Berat Kering Biji (g)}

Hasil pengamatan berat kering biji dengan pemberian pupuk NPK Grower dan Defoliasi setelah dianalisis ragam, menunjukkan bahwa pengaruh interaksi dan pengaruh utama pemberian pupuk NPK Grower dan Defoliasi berpengaruh nyata terhadap perubahan berat kering biji. Hasil uji Beda Nyata Jujur (BNJ) pada taraf 5\% dapat dilihat pada tabel 1.

Data pada tabel 1, menunjukkan bahwa interaksi pemberian pupuk NPK Grower dan Defoliasi berpengaruh nyata terhadap perubahan berat kering biji jagung. Dimana berat kering biji pada umur 15 hari setelah penyerbukan menunjukkan bahwa rerata berat kering biji tertinggi terdapat pada kombinasi perlakuan N3D3 (pupuk NPK Grower 22,5 g/tanaman dan Defoliasi semua daun di bawah tongkol) dengan rerata berat kering biji 0,65 g, yang tidak berbeda nyata dengan kombinasi perlakuan N2D3 yaitu $0,60 \mathrm{~g}, \mathrm{~N} 3 \mathrm{D} 2$ yaitu 0,60 
g, N0D2 yaitu 0,60 g, N2D2 yaitu $0,60 \mathrm{~g}$, N1D3 yaitu 0,60 g, N3D1 yaitu $0,60 \mathrm{~g}$ dan N3D0 yaitu 0,60 g, namun berbeda nyata dengan kombinasi perlakuan lainnya. Sedangkan rerata berat kering terendah terdapat pada kombinasi perlakuan N2D0 yaitu 0,40 g, yang berbeda nyata dengan kombinasi perlakuan N3D3 dan N2D3 dengan rerata berat kering biji masing-masing yaitu $0,65 \mathrm{~g}$ dan 0,60 $\mathrm{g}$, namun tidak berbeda nyata dengan kombinasi perlakuan lainnya.

Tabel 1.Rerata perubahan berat kering biji jagung dengan pemberian pupuk NPK Grower dan Defoliasi (g).

\begin{tabular}{|c|c|c|c|c|c|c|}
\hline \multirow{2}{*}{$\begin{array}{l}\text { Hari Setelah } \\
\text { Penyerbukan }\end{array}$} & \multirow{2}{*}{$\begin{array}{r}\text { NPK Grower } \\
(\mathrm{g} / \text { tanaman })\end{array}$} & \multicolumn{4}{|c|}{ Defoliasi (daun di bawah tongkol) } & \multirow{2}{*}{ Rerata } \\
\hline & & D0 (0) & D1 (2) & D2 (4) & D3 (semua) & \\
\hline \multirow{6}{*}{15} & N0 (0) & $0,43 \mathrm{c}$ & $0,42 \mathrm{c}$ & $0,53 \mathrm{abc}$ & $0,48 \mathrm{bc}$ & $0,47 \mathrm{~b}$ \\
\hline & $\mathrm{N} 1(7,5)$ & $0,48 \mathrm{bc}$ & $0,43 \mathrm{c}$ & $0,43 \mathrm{c}$ & $0,52 \mathrm{abc}$ & $0,47 \mathrm{~b}$ \\
\hline & N2 (15) & $0,40 \mathrm{c}$ & $0,47 \mathrm{bc}$ & $0,53 \mathrm{abc}$ & $0,60 \mathrm{ab}$ & $0,50 \mathrm{ab}$ \\
\hline & N3 $(22,5)$ & $0,50 \mathrm{abc}$ & $0,52 \mathrm{abc}$ & $0,55 \mathrm{abc}$ & $0,65 \mathrm{a}$ & $0,55 \mathrm{a}$ \\
\hline & Rerata & $0,45 \mathrm{c}$ & $0,46 \mathrm{bc}$ & $0,51 \mathrm{ab}$ & $0,56 \mathrm{a}$ & \\
\hline & \multicolumn{2}{|c|}{$\mathrm{KK}=9,63 \%$} & $\mathrm{BNJ} N=0,05$ & \multicolumn{2}{|c|}{$\mathrm{BNJ} D=0,05$} & 0,15 \\
\hline \multirow{6}{*}{25} & No (0) & $1,32 \mathrm{c}$ & $1,40 \mathrm{bc}$ & $1,55 \mathrm{bc}$ & $1,55 \mathrm{bc}$ & $1,45 \mathrm{c}$ \\
\hline & $\mathrm{N} 1(7,5)$ & $1,47 \mathrm{bc}$ & $1,42 \mathrm{bc}$ & $1,50 \mathrm{bc}$ & $1,63 \mathrm{abc}$ & $1,50 \mathrm{bc}$ \\
\hline & N2 (15) & $1,45 \mathrm{bc}$ & $1,62 \mathrm{abc}$ & $1,68 \mathrm{ab}$ & $1,62 \mathrm{abc}$ & $1,59 \mathrm{ab}$ \\
\hline & N3 $(22,5)$ & $1,55 \mathrm{bc}$ & $1,55 \mathrm{bc}$ & $1,57 \mathrm{bc}$ & $1,93 \mathrm{a}$ & $1,65 \mathrm{a}$ \\
\hline & Rerata & $1,45 \mathrm{c}$ & $1,50 \mathrm{bc}$ & $1,58 \mathrm{ab}$ & $1,68 \mathrm{a}$ & \\
\hline & $\mathrm{KK}=6,60 \%$ & \multicolumn{2}{|c|}{ BNJ $\mathrm{N}=0,11$} & $\mathrm{D}=0,11$ & BNJ ND $=0,31$ & \\
\hline \multirow{6}{*}{35} & N0 (0) & $1,83 \mathrm{~g}$ & $1,88 \mathrm{~g}$ & 2,00 efg & 2,02 defg & $1,93 \mathrm{~d}$ \\
\hline & $\mathrm{N} 1(7,5)$ & $1,97 \mathrm{~g}$ & $1,98 \mathrm{fg}$ & $2,17 \mathrm{cdef}$ & $2,23 \mathrm{bc}$ & $2,09 \mathrm{c}$ \\
\hline & N2 (15) & 2,02 defg & $2,20 \mathrm{bcd}$ & $2,25 \mathrm{bc}$ & $2,37 \mathrm{~b}$ & $2,21 \mathrm{~b}$ \\
\hline & N3 $(22,5)$ & 2,17 cdef & 2,18 bcde & $2,33 \mathrm{bc}$ & $2,65 \mathrm{a}$ & $2,33 \mathrm{a}$ \\
\hline & Rerata & $2,00 \mathrm{c}$ & $2,06 \mathrm{c}$ & $2,19 \mathrm{~b}$ & $2,32 \mathrm{a}$ & \\
\hline & $\mathrm{KK}=2,92 \%$ & \multicolumn{2}{|c|}{$\mathrm{BNJ} N=0,07$} & $\mathrm{D}=0,07$ & $\mathrm{BNJ} N D=0,19$ & \\
\hline \multirow{6}{*}{43} & N0 (0) & $2,32 \mathrm{f}$ & 2,38 ef & $2,43 \mathrm{def}$ & 2,48 cde & $2,40 \mathrm{c}$ \\
\hline & $\mathrm{N} 1(7,5)$ & 2,52 bcde & $2,57 \mathrm{bcd}$ & $2,62 \mathrm{bc}$ & 2,52 bcde & $2,55 \mathrm{~b}$ \\
\hline & N2 (15) & $2,50 \mathrm{bcde}$ & $2,62 \mathrm{bc}$ & $2,65 \mathrm{ab}$ & $2,62 \mathrm{bc}$ & $2,60 \mathrm{ab}$ \\
\hline & N3 $(22,5)$ & $2,57 \mathrm{bcd}$ & $2,60 \mathrm{bc}$ & $2,62 \mathrm{bc}$ & $2,80 \mathrm{a}$ & $2,65 \mathrm{a}$ \\
\hline & Rerata & $2,48 \mathrm{c}$ & $2,54 \mathrm{~b}$ & $2,58 \mathrm{ab}$ & $2,60 \mathrm{a}$ & \\
\hline & $\mathrm{KK}=1,99 \%$ & \multicolumn{2}{|c|}{ BNJ $N=0,05$} & $\mathrm{D}=0,05$ & $\mathrm{BNJ} N \mathrm{ND}=0,15$ & \\
\hline
\end{tabular}

Angka-angka pada baris dan kolom yang diikuti huruf kecil yang sama menunjukan tidak berbeda nyata menurut uji lanjut BNJ pada taraf $5 \%$.

Kemudian berat kering biji pada umur 25 hari setelah penyerbukan menunjukkan bahwa kombinasi perlakuan N3D3 (pupuk NPK Grower 22,5 g/tanaman dan Defoliasi semua daun di bawah tongkol) memiliki rerata berat kering tertinggi yaitu $1,93 \mathrm{~g}$, yang tidak berbeda nyata dengan kombinasi perlakuan N2D2 dengan rerata berat kering biji 1,68 g, N1D3 dengan rerata berat kering biji 1,63 g, N2D1 dan N2D3 yang sama-sama memiliki rerata berat kering biji yaitu 1,62 g, namun berbeda nyata dengan kombinasi perlakuan lainnya. Sedangkan rerata berat kering terendah terdapat pada kombinasi perlakuan N0D0 yaitu 1,32 g, yang berbeda nyata dengan kombinasi perlakuan N3D3 dan N2D2 dengan rerata berat kering biji masing-masing yaitu 1,93 g dan 1,68 $\mathrm{g}$, dan tidak berbeda nyata dengan perlakuan lainnya.

Selanjutnya berat kering biji pada umur 35 hari setelah penyerbukan menunjukkan bahwa rerata berat kering biji tertinggi terdapat pada kombinasi perlakuan N3D3 (pupuk NPK Grower 22,5 g/tanaman dan Defoliasi semua daun di bawah tongkol) yaitu $2,65 \mathrm{~g}$, yang berbeda nyata dengan kombinasi perlakuan lainnya. Sedangkan rerata berat kering terendah terdapat pada kombinasi perlakuan NOD0 yaitu $1,83 \mathrm{~g}$, yang tidak berbeda nyata dengan 
kombinasi perlakuan N0D1 yaitu 1,88 g, N1D0 yaitu $1,97 \mathrm{~g}, \mathrm{~N} 1 \mathrm{D} 1$ yaitu $1,98 \mathrm{~g}, \mathrm{~N} 0 \mathrm{D} 2$ yaitu 2,00 g, N0D3 yaitu 2,02 g dan N2D0 yaitu 2,02 $\mathrm{g}$, namun berbeda nyata dengan kombinasi perlakuan lainnya.

Kemudian berat kering biji pada 43 hari setelah penyerbukan atau saat panen menunjukkan bahwa rerata berat kering biji tertinggi terdapat pada kombinasi perlakuan N3D3 (pupuk NPK Grower 22,5 g/tanaman dan Defoliasi semua daun di bawah tongkol) yaitu $2,80 \mathrm{~g}$, yang tidak berbeda nyata dengan kombinasi perlakuan N2D2 dengan rerata berat kering biji 2,65 g, namun berbeda nyata dengan kombinasi perlakuan lainnya. Sedangkan rerata berat kering terendah terdapat pada kombinasi perlakuan NOD0 yaitu dengan rerata 2,32 g, yang tidak berbeda nyata dengan kombinasi perlakuan NOD1 dan NOD2 dengan rerata berat kering biji masing-masing yaitu $2.38 \mathrm{~g}$ dan 2,43 $\mathrm{g}$, namun berbeda nyata dengan kombinasi perlakuan lainnya.

Berat kering biji pada perlakuan N3D3 (pupuk NPK Grower 22,5 g/tanaman dan Defoliasi semua daun di bawah tongkol) lebih tinggi dari perlakuan lainnya karena pupuk NPK grower merupakan pupuk majemuk yang sangat cepat tersedia dan dapat dimanfaatkan langsung oleh tanaman sehingga dapat memacu pertumbuhan tanaman serta meningkatkan kualitas buah dan hasil produksi. Sedangkan Defoliasi daun di bawah tongkol berperan dalam mengurangi persaingan internal antara bagian vegetatif dengan generatif tanaman dalam pemanfaatan asimilat hasil fotsintesis, sehingga asimilat dapat terfokus kepada pengisian biji yang kemudian berpengaruh terhadap berat kering biji tanaman jagung tersebut.

Menurut Iskandar (2010), penggunan pupuk anorganik yang berimbang dapat meningkatkan pertumbuhan dan hasil jagung serta dapat memberikan tingkat produksi jagung yang tinggi. Nitrogen (N) sebagai bahan pembentuk khlorofil daun sangat diperlukan untuk memacu proses fotosintesis daun. Selain itu nitrogen (N) juga sebagai pembentuk senyawa asam-asam amino dan protein untuk pertumbuhan tanaman.Fosfat (P) sangat diperlukan untuk energi pertumbuhan (ATP) termasuk pembentukan biji, sementara kalium (K) memacu translokasi hasil fotosintesis dari daun ke bagian lain tanaman dan berperan untuk pembentukan karbohidrat tanaman (Marschner dalamSyafruddin 2010). Selanjutnya unsur fospat (P) mampu meningkatkan proses fotosintesis yang selanjutnya akan berpengaruh pula pada peningkatan berat kering.

Pratikta (2013) menyatakan bahwa semakin besar fotosintat yang dipartisi atau dialokasikan ke bagian tongkol semakin besar pula penimbunan cadangan makanan yang ditranslokasikan ke biji sehingga meningkatkan berat biji, namun sebaliknya semakin menurun fotosintat yang dipartisi atau dialokasikan ke bagian tongkol maka semakin rendah pula penimbunan cadangan makanan yang ditranslokasikan ke biji sehingga menurunkankan berat biji. Dengan dilakukannya pemangkasan daun di bawah tongkol maka daun tersebut tidak lagi mengambil hasil fotosintesis sehingga hasil fotosintesis tersebut dapat lebih dioptimalkan ke pengisian biji.Hal ini sesuai dengan yang dikemukakan Bustamam (2004) bahwa 25\% daun pada bagian atas memainkan peran penting dalam pengisian biji.

Berat kering terendah terdapat pada perlakuan kontrol (NOD0), hal ini diduga karena tanaman tidak dapat memenuhi kebutuhan nutrisinya untuk dapat tumbuh dan berkembang dengan baik.Unsur hara yang terbatas dapat membatasi pertumbuhan tanaman sementara bagian tanaman memerlukan asupan nutrisi yang cukup untuk dapat berkembang dengan normal.Bahan asimilat yang dihasilkan oleh tanaman tidak dapat digunakan secara optimal karena daun bagian bawah (daun negatif) secara keseluruhan merugikan tanaman itu sendiri, sehingga dalam praktik budidaya adanya daun negatif sebaiknya didefoliasi.Menurut Legwaila et al., (2013) bahwa dampak kerugian berkaitan erat dengan tahap perkembangan tanaman dan luas daun optimum harus diproduksi untuk mencapai potensi hasil maksimal pada tanaman.

Berat benih per biji berkaitan erat dengan efektif atau tidaknya pengisian biji. Pengisian biji yang sempurna jelas akan menghasilkan benih yang berat, sebaliknya bila tanaman mengalami stress akan menyebabkan benih yang dihasilkan akan ringan atau jumlah benih yang dihasilkan akan sedikit (Bustamam, 2004). 


\section{Perubahan Kadar Air Biji (\%)}

Hasil pengamatan perubahan kadar air biji dengan pemberian pupuk NPK Grower dan Defoliasi setelah dianalisis ragam, menunjukkan bahwa pengaruh interaksi pemberian pupuk NPK Grower dan Defoliasi tidak berpengaruh nyata terhadap perubahan kadar air biji jagung pada pengamatan 15, 25 dan 35 hari setelah penyerbukan, namun berpengaruh nyata pada pengamatan 43 hari setelah penyerbukan. Sedangkan pengaruh utama dari masing-masing perlakuan memberikan pengaruh yang nyata terhadap perubahan kadar air biji. Hasil uji Beda Nyata Jujur (BNJ) pada taraf 5\% dapat dilihat pada tabel 2.

Data pada Tabel 2 menunjukkan bahwa pada umur 15 hari setelah penyerbukan, perlakuan pupuk NPK Grower secara tunggal memberikan pengaruh yang nyata terhadap perubahan kadar air biji jagung. Perlakuan yang terbaik terdapat pada perlakuan N3 (pupuk NPK Grower 22,5 g/tanaman) dengan rerata kadar air biji 75,03\%, yang tidak berbeda nyata dengan perlakuan $\mathrm{N} 2$ dengan rerata kadar air biji $74,22 \%$ dan $\mathrm{N} 1$ yaitu $73,27 \%$, namun berbeda nyata dengan perlakuan N0 yaitu 71,02 $\%$. Sedangakan perlakuan N0 tidak berbeda nyata dengan perlakuan $\mathrm{N} 1$, namun berbeda nyata dengan perlakuan N2 dan N3.Perlakuan Defoliasi secara tunggal memberikan pengaruh yang nyata terhadap perubahan kadar air biji jagung. Dimana perlakuan terbaik terdapat pada perlakuan D3 (Defoliasi semua daun di bawah tongkol) dengan rerata kadar air biji 75,81\%, yang berbeda nyata dengan perlakuan lainnya. Kadar air biji terendah terdapat pada perlakuan D0 yaitu dengan rerata kadar air biji 72,04\% yang tidak berbeda nyata dengan D1 dan D2 dengan rerata kadar air biji masing-masing yaitu $72,41 \%$ dan $73,29 \%$, namun berbeda nyata dengan D3 dengan rerata kadar air biji yaitu $75,81 \%$.

Tabel 2. Rerata perubahan kadar air biji jagung dengan pemberian pupuk NPK Grower dan Defoliasi (\%)

\begin{tabular}{|c|c|c|c|c|c|c|}
\hline \multirow{2}{*}{$\begin{array}{l}\text { Hari Setelah } \\
\text { Penyerbukan }\end{array}$} & \multirow[t]{2}{*}{$\begin{array}{r}\text { NPK Grower } \\
(\mathrm{g} / \text { tanaman }) \\
\end{array}$} & \multicolumn{4}{|c|}{ Defoliasi (daun di bawah tongkol) } & \multirow{2}{*}{ Rerata } \\
\hline & & D0 (0) & D1 (2) & D2 (4) & D3 (semua) & \\
\hline \multirow{6}{*}{15} & N0 (0) & 69,83 & 70,18 & 70,58 & 73,51 & $71,02 \mathrm{~b}$ \\
\hline & $\mathrm{N} 1(7,5)$ & 72,31 & 71,91 & 72,71 & 76,14 & $73,27 \mathrm{ab}$ \\
\hline & N2 (15) & 72,50 & 73,75 & 74,36 & 76,27 & $74,22 \mathrm{a}$ \\
\hline & N3 $(22,5)$ & 73,51 & 73,80 & 75,50 & 77,32 & $75,03 \mathrm{a}$ \\
\hline & Rerata & $72,04 \mathrm{~b}$ & $72,41 \mathrm{~b}$ & $73,29 \mathrm{~b}$ & $75,81 \mathrm{a}$ & \\
\hline & $\mathrm{KK}=2,80 \%$ & \multicolumn{2}{|c|}{ BNJ N $=2,28$} & $\mathrm{D}=2,28$ & & \\
\hline \multirow{6}{*}{25} & N0 (0) & 49,51 & 51,34 & 51,40 & 52,52 & $51,19 \mathrm{c}$ \\
\hline & $\mathrm{N} 1(7,5)$ & 50,85 & 51,48 & 52,88 & 53,73 & $52,23 \mathrm{bc}$ \\
\hline & N2 (15) & 52,09 & 51,91 & 53,65 & 53,81 & $52,86 \mathrm{ab}$ \\
\hline & N3 $(22,5)$ & 52,55 & 54,18 & 53,62 & 55,72 & $54,02 \mathrm{a}$ \\
\hline & Rerata & $51,25 \mathrm{c}$ & $52,22 \mathrm{bc}$ & $52,89 \mathrm{ab}$ & $53,95 \mathrm{a}$ & \\
\hline & $\mathrm{KK}=2,30 \%$ & \multicolumn{2}{|c|}{ BNJ $\mathrm{N}=1,34$} & $\mathrm{D}=1,34$ & & \\
\hline \multirow{6}{*}{35} & N0 (0) & 35,52 & 39,22 & 38,36 & 39,10 & $38,05 \mathrm{~b}$ \\
\hline & $\mathrm{N} 1(7,5)$ & 37,60 & 37,58 & 39,12 & 40,10 & $38,60 \mathrm{~b}$ \\
\hline & N2 (15) & 38,40 & 38,48 & 38,90 & 40,20 & $38,99 \mathrm{~b}$ \\
\hline & $\mathrm{N} 3(22,5)$ & 40,76 & 40,68 & 40,51 & 41,35 & $40,83 \mathrm{a}$ \\
\hline & Rerata & $38,07 \mathrm{~b}$ & $38,99 \mathrm{ab}$ & $39,22 \mathrm{ab}$ & $40,19 \mathrm{a}$ & \\
\hline & $\mathrm{KK}=3,29 \%$ & \multicolumn{2}{|c|}{$\mathrm{BNJ} \mathrm{N}=1,43$} & $\mathrm{D}=1,43$ & & \\
\hline \multirow{6}{*}{43} & N0 (0) & $31,50 \mathrm{~b}$ & $31,56 \mathrm{~b}$ & $32,03 \mathrm{~b}$ & $31,51 \mathrm{~b}$ & $31,65 \mathrm{c}$ \\
\hline & $\mathrm{N} 1(7,5)$ & $31,69 \mathrm{~b}$ & $32,49 \mathrm{~b}$ & $32,79 \mathrm{~b}$ & $32,22 \mathrm{~b}$ & $32,30 \mathrm{bc}$ \\
\hline & N2 (15) & $32,38 \mathrm{~b}$ & $32,61 \mathrm{~b}$ & $33,11 \mathrm{~b}$ & $33,33 \mathrm{~b}$ & $32,86 \mathrm{~b}$ \\
\hline & N3 $(22,5)$ & $32,52 \mathrm{~b}$ & $33,16 \mathrm{~b}$ & $33,55 \mathrm{ab}$ & $35,41 \mathrm{a}$ & $33,66 \mathrm{a}$ \\
\hline & Rerata & $32,02 \mathrm{~b}$ & $32,45 \mathrm{ab}$ & $32,87 \mathrm{a}$ & $33,12 \mathrm{a}$ & \\
\hline & $\mathrm{KK}=2,08 \%$ & \multicolumn{2}{|c|}{$\mathrm{BNJ} N=0,75$} & $\mathrm{D}=0,75$ & $\mathrm{BNJ} \mathrm{ND}=$ & \\
\hline
\end{tabular}

Angka-angka pada baris dan kolom yang diikuti huruf kecil yang sama menunjukan tidak berbeda nyata menurut uji lanjut 
Kemudian pada umur 25 hari setelah penyerbukan perlakuan pupuk NPK Grower secara tunggal memberikan pengaruh yang nyata terhadap perubahan kadar air biji, dimana rerata kadar air biji tertinggi terdapat pada perlakuan N3 (pupuk NPK Grower 22,5 g/tanaman) yaitu 54,02 \%, yang tidak berbeda nyata dengan perlakuan N2 yaitu 52,86\% namun berbeda nyata dengan perlakuan N1 dengan rerata kadar air biji 52,23\%, dan N0 yaitu 51,19\%. Perlakuan N2 tidak berbeda nyata dengan perlakuan $\mathrm{N} 1$, namun berbeda nyata dengan perlakuan No.Sedangkan perlakuan N1 tidak berbeda nyata dengan perlakuan N0. Perlakuan Defoliasi secara tunggal memberikan pengaruh yang nyata terhadap perubahan kadar air biji jagung. Dimana rerata kadar air biji tertinggi terdapat pada perlakuan D3 (Defoliasi semua daun di bawah tongkol) yaitu 53,95 \%, yang tidak berbeda nyata dengan perlakuan D2 yaitu 52,89 $\%$, namun berbeda nyata dengan perlakuan D1 dengan kadar air biji 52,22\% dan D0 yaitu $51,25 \%$. Sedangkan perlakuan D2 tidak berbeda nyata dengan perlakuan D1 namun berbeda nyata dengan perlakuan D0.Perlakuan D1 tidak berbeda nyata dengan perlakuan D0.

Kemudian pada umur 35 hari setelah penyerbukan perlakuan pupuk NPK Grower secara tunggal memberikan pengaruh yang nyata terhadap perubahan kadar air biji, dimana perlakuan N3 (pupuk NPK Grower 22,5 g/tanaman) memiliki rerata kadar air biji tertinggi yaitu 40,83 \%, yang berbeda nyata dengan perlakuan lainnya, dimana N2, N1 dan N0 memiliki kadar air masing-masing yaitu $38,99 \%, 38,60 \%$ dan 38,05 \%. Sedangkan perlakuan N2 tidak berbeda nyata dengan perlakuan N1 dan N0. Perlakuan Defoliasi secara tunggal berpengaruh nyata terhadap perubahan kadar air biji jagung. Dimana rerata kadar air biji tertinggi terdapat pada perlakuan D3 (Defoliasi semua daun di bawah tongkol) yaitu $40.19 \%$, yang tidak berbeda nyata dengan perlakuan D2 dan D1 dengan rerata kadar air biji masing-masing yaitu 39,22 \% dan 38,99\%, namun berbeda nyata dengan perlakuan D0 yaitu 38,07\%. Sedangkan perlakuan D0 tidak berbeda nyata dengan perlakuan D2 dan D1 namun berbeda nyata dengan D3.
Pada tabel 2 menunjukkan bahwa interaksi pemberian pupuk NPK Grower dan Defoliasi berpengaruh nyata terhadap perubahan kadar air biji pada umur 43 hari setelah penyerbukan atau saat panen. Dimana kombinasi perlakuan N3D3 (pupuk NPK Grower 22,5 g/tanaman dan Defoliasi semua daun di bawah tongkol) memiliki rerata kadar air biji tertinggi yaitu $35,41 \%$, yang tidak berbeda nyata dengan kombinasi perlakuan N3D2 yang memiliki kadar air biji 33,55\%, namun berbeda nyata dengan kombinasi perlakuan lainnya. Sedangkan rerata kadar air terendah terdapat pada kombinasi perlakuan kontrol (NOD0) yaitu 31,50\% yang berbeda nyata dengan kombinasi perlakuan N3D3 namun tidak berbeda nyata dengan kombinasi perlakuan lainnya.

Kadar air biji pada perlakuan N3D3 (pupuk NPK Grower 22,5 g/tanaman dan Defoliasi semua daun di bawah tongkol) lebih tinggi dari perlakuan lainnya karena pupuk NPK grower merupakan salah satu pupuk yang cepat tersedia dan dimanfaatkan langsung oleh tanaman sehingga dapat memacu pertumbuhan tanaman serta meningkatkan kualitas buah dan hasil produksi (Anonimus, 2003). Sedangkan Defoliasi daun di bawah tongkol dapat membantu tanaman dalam meminimalisasi kehilangan air pada tanaman yaitu dengan mengurangi laju transpirasi.

Tanaman yang daunnya tidak dipangkas lebih sedikit persentase kadar airnya karena tanaman tersebut bertranspirasi bebas. Sebagaimana yang dijelaskan oleh Fitter dan Hay dalam Razali (2008), Pemangkasan daun juga membantu dalam upaya meminimalisasi kehilangan air pada tanaman yaitu dengan mengurangi laju transpirasi.Karena tanaman yang bertranspirasi bebas, air dievaporasi dari dinding sel epidermis yang lembab di bagian dalam daun dan hilang ke atmosfer melalui stomata. Dengan demikian tanaman yang daunnya dipangkas memiliki kadar air yang lebih tinggi dibandingkan dengan tanaman yang tidak dipangkas. 


\section{Kecepatan Penumpukan Bahan Kering/ KPBK (mg/biji/hari)}

Hasil pengamatan kecepatan penumpukan bahan kering dengan pemberian pupuk NPK Grower dan Defoliasi setelah dianalisis ragam, menunjukkan bahwa pengaruh interaksi dan pengaruh utama pemberian pupuk NPK Grower dan Defoliasi berpengaruh nyata terhadap kecepatan penumpukan bahan kering. Hasil uji Beda Nyata Jujur (BNJ) pada taraf 5\% dapat dilihat pada tabel 4.BNJ pada taraf 5\% dapat dilihat pada Tabel 3.

Tabel 3.Rerata kecepatan penumpukan bahan kering biji jagung dengan pemberian pupuk NPK Grower dan Defoliasi (mg/biji/hari).

\begin{tabular}{|c|c|c|c|c|c|}
\hline \multirow{2}{*}{$\begin{array}{c}\text { NPK Grower } \\
\text { (g/tanaman) }\end{array}$} & \multicolumn{4}{|c|}{ Defoliasi (daun di bawah tongkol) } & \multirow[b]{2}{*}{ Rerata } \\
\hline & D0 (0) & D1 (2) & D2 (4) & D3 (semua) & \\
\hline N0 (0) & $70 \mathrm{~g}$ & $73,33 \mathrm{fg}$ & $73,33 \mathrm{fg}$ & 76,67 defg & $73,33 \mathrm{~d}$ \\
\hline N1 $(7,5)$ & 74,17 efg & 77,50 cdefg & $86,67 \mathrm{bc}$ & $85,83 \mathrm{bcd}$ & $81,04 \mathrm{c}$ \\
\hline N2 (15) & 80,83 bcdef & $86,67 \mathrm{bc}$ & $85,83 \mathrm{bcd}$ & $88,33 \mathrm{~b}$ & $85,42 \mathrm{~b}$ \\
\hline $\mathrm{N} 3(22,5)$ & 83,33 bcde & 83,33 bcde & $89,17 \mathrm{~b}$ & $100 \mathrm{a}$ & $88,96 \mathrm{a}$ \\
\hline Rerata & $77,08 \mathrm{c}$ & $80,21 \mathrm{c}$ & $83,75 \mathrm{~b}$ & $87,71 \mathrm{a}$ & \\
\hline $\mathrm{KK}=3,67 \%$ & $\mathrm{BNJ} N=3,35$ & $\mathrm{BNJ} \mathrm{D}=3,35$ & $3 \mathrm{NJ} \mathrm{ND}=$ & & \\
\hline
\end{tabular}

Angka-angka pada baris dan kolom yang diikuti huruf kecil yang sama menunjukan tidak berbeda nyata menurut uji lanjut BNJ pada taraf $5 \%$.

Tabel 3 menunjukkan bahwa kombinasi perlakuan pupuk NPK Grower dan Defoliasi berpengaruh nyata terhadap kecepatan penumpukan bahan kering. Dimana kombinasi perlakuan N3D3 (pupuk NPK Grower 22,5 g/tanaman dan Defoliasi semua daun di bawah tongkol) memiliki kecepatan penumpukan bahan kering tertinggi yaitu $100 \mathrm{mg} /$ biji/hari yang berbeda nyata dengan kombinasi perlakuan lainnya. Sedangkan kecepatan penumpukan bahan kering terendah terdapat pada kombinasi perlakuan NOD0 yaitu 70 $\mathrm{mg} / \mathrm{biji} / \mathrm{hari}$, yang tidak berbeda nyata dengan kombinasi perlakuan N0D1 yaitu 73,33 mg/biji/hari, N0D2 yaitu 73,33 mg/biji/hari, N0D3 yaitu 76,67 mg/biji/hari, NID0 yaitu $74,17 \mathrm{mg} / \mathrm{biji} / \mathrm{hari}$ dan NID2 yaitu 77,50 $\mathrm{mg} / \mathrm{biji} / \mathrm{hari}$, namun berbeda nyata dengan kombinasi perlakuan lainnya.

Rerata tertinggi pada parameter kecepatan penumpukan bahan kering terdapat pada kombinasi perlakuan N3D3 (pupuk NPK Grower 22,5 g/tanaman dan Defoliasi semua daun di bawah tongkol), hal ini disebabkan karena pupuk NPK Grower memberikan reaksi super cepat pada tanaman sehingga laju pengisian bahan kering ke biji dapat berjalan dengan lebih cepat. Seperti yang dijelaskan oleh Anonimus (2003), bahwa Nitrogen yang terdapat dalam pupuk NPK Grower berbentuk NO3 (Nitrat) yang langsung tersedia bagi tanaman dan dapat membantu penyerapan unsur hara Kalium, Magnesium, Sulfur, Boron, Mangan dan Zinc sehingga dapat mempercepat proses pembungaan, pembuahan dan memacu pertumbuhan pada pucuk tanaman serta menekan serangan jamur dan penyakit.

Defoliasi dilakukan dengan membuang bagian vegetatif yang tidak produktif terutama daun-daun di bawah tongkol, sehingga energi atau bahan makanan yang dihasilkan akan mengalir pada pembungaan dan pembuahan, dengan demikian perkembangan tongkol akan lebih cepat (Fitter dan Hay dalam Razali, 2008). Selanjutnya Suminarti (2000), menjelaskan bahwa pengambilan daun (Defoliasi) pada daun-daun yang lebih bersifat parasit dapat menyokong hasil panen secara nyata. Defoliasi yang tepat dapat mengalihkan fotosintat pada perkembangan generatif.

Kecepatan penumpukan bahan kering terendah terdapat pada kombinasi perlakuan kontrol (NOD0) yaitu $70 \mathrm{mg} / \mathrm{biji} / \mathrm{hari}$.hal ini disebabkan karena tanaman tidak diberikan pupuk NPK Grower sehingga menyebabkan asupan unsur hara menjadi berkurang. Menurut Rukmana (1997), kekahatan unsur hara akan menyebabkan penghambatan pertumbuhan generatif tanaman karena adanya upaya pemaksimalan penggunaan hara dan asimilat untuk memacu pertumbuhan vegetatif tanaman.

Dilaporkan oleh Harjadi dalam Bustaman (2004) bahwa laju asmilasi pada daun tua dan daun yang terdapat di bagian bawah adalah 
lebih rendah dibandingkan dengan daun muda atau daun yang di bagian atas dari tanaman jagung. Efisiensi daun tanaman jagung akan menurun dari bagian atas ke bagian bawah tanaman. Jika tanaman dipangkas, maka efisiensi daun bagian atas akan meningkat. Translokasi asimilat ke biji dari daun jagung bagian atas lebih cepat dari pada daun bagian bawah.

Menurut Ismail, Saefuddin dan Zulfica dalam Razali (2008), pada saat fase generatif berlangsung maka sebagian besar hasil asimilasi akan ditranslokasikan ke bagian jaringan penyimpanan sehingga dapat menyebabkan terjadinya persaingan antara bagian vegetatif maupun bagian organ generatif tanaman, terutama dalam memanfaatkan hasilhasil asimilasi dari sumber ke bagian sink atau pengguna. Fitter dan Hay dalam Razali (2008), menambahkan bahwa daun-daun yang tua ataupun daun-daun yang tertutupi akan berpengaruh pada penyerapan cahaya matahari yang berfungsi untuk fotosintesis. Daun-daun ini juga menggunakan asimilat yang seharusnya disalurkan ke bagian tongkol jagung.

\section{Waktu Pengisian Efektif (hari)}

Hasil pengamatan waktu pengisian efektif dengan pemberian pupuk NPK Grower dan Defoliasi setelah dianalisis ragam, menunjukkan bahwa pengaruh interaksi pemberian pupuk NPK Grower dan Defoliasi tidak berpengaruh nyata. Namun pengaruh utama masing-masing faktor perlakuan berpengaruh nyata terhadap waktu pengisian efektif.Hasil uji Beda Nyata Jujur (BNJ) pada taraf 5\% dapat dilihat pada tabel 4 .

Tabel 4.Rerata waktu pengisian efektif biji jagung dengan pemberian pupuk NPK Grower dan Defoliasi (hari).

\begin{tabular}{|c|c|c|c|c|c|}
\hline \multirow{2}{*}{$\begin{array}{c}\text { NPK Grower } \\
(\mathrm{g} / \mathrm{tanaman})\end{array}$} & \multicolumn{4}{|c|}{ Defoliasi (daun di bawah tongkol) } & \multirow[b]{2}{*}{ Rerata } \\
\hline & D0 (0) & D1 (2) & D2 (4) & D3 (semua) & \\
\hline N0 (0) & 33,42 & 32,59 & 33,28 & 32,42 & $32,93 \mathrm{c}$ \\
\hline N1 $(7,5)$ & 33,94 & 33,22 & 30,28 & 29,43 & $31,72 b c$ \\
\hline $\mathrm{N} 2(15)$ & 31,18 & 30,26 & 30,95 & 29,67 & $30,52 \mathrm{ab}$ \\
\hline N3 $(22,5)$ & 30,88 & 31,32 & 29,45 & 28,03 & $29,92 \mathrm{a}$ \\
\hline Rerata & $32,35 \mathrm{~b}$ & $31,85 \mathrm{~b}$ & $30,99 \mathrm{ab}$ & $29,89 \mathrm{a}$ & \\
\hline
\end{tabular}

$\mathrm{KK}=4,62 \% \quad \mathrm{BNJ} \mathrm{N}=1,60 \quad \mathrm{BNJ} \mathrm{D}=1,60$

Angka-angka pada baris dan kolom yang diikuti huruf kecil yang sama menunjukan tidak berbeda nyata menurut uji lanjut BNJ pada taraf $5 \%$.

Tabel 4 menunjukkan bahwa pengaruh utama pupuk NPK Grower berpengaruh nyata terhadap waktu pengisian efektif, dimana pemberian perlakuan N3 (pupuk NPK Grower 22,5 g/tanaman) memiliki waktu pengisian efektifnya yaitu 29,92 hari dan tidak berbeda nyata dengan perlakuan $\mathrm{N} 2$ yaitu dengan waktu pengisian efektif 30,52 hari.Tetapi berbeda nyata dengan perlakuan N1 dan N0 dengan waktu pengisian efektif masing-masing 31,72 hari dan 32,93 hari.Sedangkan perlakuan N2 tidak berbeda nyata dengan N1 namun berbeda nyata dengan perlakuan No.Sedangkan perlakuan N1 tidak berbeda nyata dengan perlakuan NO.

Cepatnya waktu pengisian efektif yang terdapat pada perlakuan N3 disebabkan karena unsur fospat $(\mathrm{P})$ dan kalium $(\mathrm{K})$ yang terdapat dalam pupuk NPK Grower.Dimana fosfat (P) sangat diperlukan untuk energi pertumbuhan
(ATP) termasuk pembentukan biji, sementara kalium (K) memacu translokasi hasil fotosintesis dari daun ke bagian lain tanaman dan berperan untuk pembentukan karbohidrat tanaman (Marschner dalam Syafruddin, 2010). Selanjutnya unsur fospat (P) mampu meningkatkan proses fotosintesis yang selanjutnya akan berpengaruh pula pada peningkatan berat kering.

Dari tabel 4 menunjukkan bahwa pengaruh utama Defoliasi berpengaruh nyata terhadap waktu pengisian efektif. Dimana perlakuan D3 (Defoliasi semua daun di bawah tongkol) memiliki waktu pengisian efektifnya yaitu 29.89 hari dan tidak berbeda nyata dengan perlakuan D2 dengan waktu pengisian efektif 30.99 hari, namun berbeda nyata dengan perlakuan D1 yaitu 31,85 hari dan D0 yaitu 32,35 hari. Sedangkan perlakuan D1 tidak berbeda nyata dengan perlakuan D0. 
Cepatnya waktu pengisian efektif yang terdapat pada perlakuan D3 diduga karena dengan perlakuan defoliasi daun di bawah tongkol menyebabkan asimilat yang dihasilkan tanaman dapat mengalir ke proses pembuahan tanpa diganggu oleh bagian pengguna lain, dengan demikian waktu pengisian efektif akan berlangsung lebih cepat. Penurunan waktu pengisian efektif dapat disebabkan berkurangnya suplay bahan kering dan terganggunya fase pengisian bii. Kamil dalam Razali (2008), mengatakan bahwa lamanya waktu pengisian biji sangat ditentukan oleh ketersediaan bahan kering yang akan ditumpuk ke dalam biji.

Waktu pengisian efektif berkaitan erat dengan kecepatan penumpukan biji, dimana semakin rendah laju penumpukan bahan kering maka semakin lama waktu pengisian efektifnya, sebaliknya semakin tinggi laju penumpukan bahan kering maka semkin cepat waktu pengisian efektifnya, yang pada akhirnya berkorelasi positif dengan berat kering biji jagung saat panen. Hal ini sejalan dengan pendapat Mustafavi dan Ross dalam Bustamam (2004), yang menyatakan bahwa berat akhir benih adalah fungsi dari perkalian laju pengisian biji dengan lama pengisian biji efektif, artinya semakin rendah laju pengisian biji akan memperpanjang lama pengisian biji efektif.

\section{Umur Panen (hari)}

Hasil pengamatan umur panen dengan pemberian pupuk NPK Grower dan Defoliasi setelah dianalisis ragam, menunjukkan bahwa pengaruh interaksi dan pengaruh utama pemberian pupuk NPK Grower dan Defoliasi berpengaruh nyata terhadap umur panen tanaman jagung. Hasil uji Beda Nyata Jujur (BNJ) pada taraf 5\% dapat dilihat pada tabel 5.

Tabel 5.Rerata umur panen tanaman jagung dengan pemberian pupuk NPK Grower dan Defoliasi (hari).

\begin{tabular}{|c|c|c|c|c|c|}
\hline \multirow{2}{*}{$\begin{array}{c}\text { NPK Grower } \\
(\mathrm{g} / \text { tanaman) }\end{array}$} & \multicolumn{4}{|c|}{ Defoliasi (daun di bawah tongkol) } & \multirow{2}{*}{ Rerata } \\
\hline & D0 (0) & D1 (2) & D2 (4) & D3 (semua) & \\
\hline N0 (0) & $96,67 \mathrm{e}$ & $96,67 \mathrm{e}$ & $96,33 \mathrm{e}$ & $95,67 \mathrm{de}$ & $96,33 \mathrm{~d}$ \\
\hline $\mathrm{N} 1(7,5)$ & $96,50 \mathrm{e}$ & $95,67 \mathrm{de}$ & $93,50 \mathrm{bc}$ & $94,33 \mathrm{~cd}$ & $95,00 \mathrm{c}$ \\
\hline $\mathrm{N} 2(15)$ & $93,50 \mathrm{bc}$ & $93,50 \mathrm{bc}$ & $92,83 \mathrm{abc}$ & $93,33 \mathrm{bc}$ & $93,29 \mathrm{~b}$ \\
\hline N3 $(22,5)$ & $92,33 \mathrm{ab}$ & $92,17 \mathrm{ab}$ & $92,50 \mathrm{abc}$ & $91,33 \mathrm{a}$ & $92,08 \mathrm{a}$ \\
\hline Rerata & $94,75 \mathrm{c}$ & $94,50 \mathrm{bc}$ & $93,79 \mathrm{ab}$ & $93,67 \mathrm{a}$ & \\
\hline $\mathrm{KK}=0,65 \%$ & BNJ N $=0,67$ & $\mathrm{BNJ} D=$ & BNJ NI & 85 & \\
\hline
\end{tabular}

Angka-angka pada baris dan kolom yang diikuti huruf kecil yang sama menunjukan tidak berbeda nyata menurut uji lanjut BNJ pada taraf $5 \%$.

Tabel 5 menunjukkan bahwa kombinasi perlakuan pupuk NPK Grower dan Defoliasi berpengaruh nyata terhadap umur panen. Dimana kombinasi perlakuan N3D3 (pupuk NPK Grower 22,5 g/tanaman dan Defoliasi semua daun di bawah tongkol) memiliki umur panen tercepat yaitu 91,33 hari, yang tidak berbeda nyata dengan kombinasi perlakuan N3D1 yaitu 92,17 hari, N3D0 yaitu 92,33 hari, N3D2 yaitu 92,50 hari dan N2D2 yaitu 92,83 hari, tetapi berbeda nyata dengan kombinasi perlakuan lainnya. Umur panen terlama terdapat pada kombinasi perlakuan NOD0 yaitu 96,67 hari yang tidak berbeda nyata dengan kombinasi perlakuan N0D1 yaitu 96,67 hari, N1D0 yaitu 96,50 hari, N0D2 yaitu 96,33 hari, N0D3 yaitu 95,67 hari dan N1D1 yaitu 95,67 hari.
Umur panen tercepat terdapat pada kombinsi perlakuan N3D3 (pupuk NPK Grower 22,5 g/tanaman dan Defoliasi semua daun di bawah tongkol) yaitu 91,33 hari, hal ini disebabkan karena kombinasi perlakuan tersebut merupakan kombinasi perlakuan terbaik, karena pupuk NPK Grower merupakan pupuk majemuk yang mengandung unsur hara makro dan mikro sekaligus sehingga kebutuhan tanaman dalam pertumbuhanna dapat terpenuhi. Anonimus (2003), mengemukakan bahwa Pupuk NPK Grower dapat mempengaruhi pertumbuhan vegetatif dan generatif tanaman salah satunya ialah umur panen tanaman, karena pupuk NPK Grower merupakan salah satu jenis pupuk majemuk yang mengandung unsur hara $15 \%$ nitrogen $(\mathrm{N}), 9 \%$ fospat $(\mathrm{P})$, $20 \%$ kalium $(\mathrm{K})$, dan beberapa unsur hara 
mikro lainnya yang sangat dibutuhkan tanaman walaupun yang diperlukan hanya dalam jumlah yang relatif sedikit.

Menurut Marschner dalam Syafruddin (2010) bahwa unsur hara N ikut berperan dalam pembungaan, namun peranan nitrogen $(\mathrm{N})$ tidak terlalu besar seperti halnya peran unsur hara fospat $(\mathrm{P})$ dalam pembentukan bunga. Peranan unsur hara fospat $(\mathrm{P})$ dalam pembentukan bunga mempengaruhi pembentukan dan ukuran tongkol, karena tongkol merupakan perkembangan dari bunga betina. Marschner dalam Syafruddin (2010), menambahkan bahwa semakin tepat dan baik tingkat serapan kalium (K) yang diterima oleh tanaman akan mampu mempercepat umur panen tanaman.

Menurut Fitter dan Hay dalam Razali (2008), umur panen tanaman dipengaruhi oleh kecepatan pertumbuhan organ hasil yang berbanding lurus terhadap pertumbuhan vegetatif tanaman.Jika pertumbuhan vegetatif mampu dipersingkat dengan asupan hara dan asimilat yang terjadi maka panen dapat lebih cepat.

Pemangkasan daun pada bagian bawah tongkol juga berarti mengurangi jumlah sink (penerima) sehingga source (sumber) makanan dapat lebih banyak didistribusikan ke hasil produksi (tongkol). Semakin cepat terbentuk tongkol maka semakin cepat tanaman memasuki masa panen.Hal ini sesuai dengan yang dikemukakan Bustamam (2004) bahwa $25 \%$ daun pada bagian atas memainkan peran penting dalam pengisian biji.

Kecepatan umur panen tanaman jagung terus menurun seiring penurunan dosis pupuk NPK Grower dan Defoliasi, hal ini diduga karena penurunan dosis pupuk NPK Grower menyebabkan asupan unsur hara menjadi berkurang dan asimilat yang dihasilkan tanaman lebih banyak dipergunakan untuk pertumbuhan vegetatif tanaman. Keadaan tersebut menyebabkan pertumbuhan generatif tanaman menjadi terganggu dan membutuhkan waktu lebih lama untuk memenuhi kriteria panen. Menurut Rukmana (1997), kekahatan unsur hara akan menyebabkan penghambatan pertumbuhan generatif tanaman karena adanya upaya pemaksimalan penggunaan hara dan asimilat untuk memacu pertumbuhan vegetatif tanaman.

Menurut Ismail, Saefuddin dan Zulfica dalam Razali (2008), pada saat fase generatif berlangsung maka sebagian besar hasil asimilasi akan ditranslokasikan ke bagian jaringan penyimpanan sehingga dapat menyebabkan terjadinya persaingan antara bagian vegetatif maupun bagian organ generatif tanaman, terutama dalam memanfaatkan hasilhasil asimilasi dari sumber ke bagian sink atau pengguna. Fitter dan Hay dalam Razali (2008), menambahkan bahwa daun-daun yang tua ataupun daun-daun yang tertutupi akan berpengaruh pada penyerapan cahaya matahari yang berfungsi untuk fotosintesis. Daun-daun ini juga menggunakan asimilat yang seharusnya disalurkan ke bagian tongkol jagung.

\section{Berat Pipilan Kering (g)}

Hasil pengamatan berat pipilan kering dengan pemberian pupuk NPK Grower dan Defoliasi setelah dianalisis ragam, menunjukkan bahwa pengaruh interaksi dan pengaruh utama pemberian pupuk NPK Grower dan Defoliasi berpengaruh nyata terhadap berat pipilan kering biji jagung. Hasil uji Beda Nyata Jujur (BNJ) pada taraf 5\% dapat dilihat pada tabel 5.

Tabel 5.Rerata berat pipilan kering biji jagung dengan pemberian pupuk NPK Grower dan Defoliasi (g).

\begin{tabular}{llllll}
\hline \multirow{2}{*}{$\begin{array}{c}\text { NPK Grower } \\
\text { (g/tanaman) }\end{array}$} & \multicolumn{3}{c}{ Defoliasi (daun di bawah tongkol) } & \multirow{2}{*}{ Rerata } \\
\cline { 2 - 4 } N0 $(0)$ & $102,23 \mathrm{~h}$ & \multicolumn{1}{c}{ D1 $(2)$} & D2 $(4)$ & D3 (semua) & \\
N1 $(7,5)$ & $121,30 \mathrm{def}$ & $122,90 \mathrm{gh}$ & $112,47 \mathrm{fgh}$ & $117,00 \mathrm{efg}$ & $109,90 \mathrm{c}$ \\
N2 $(15)$ & $125,40 \mathrm{cde}$ & $127,87 \mathrm{bcd}$ & $124,57 \mathrm{cde}$ & $123,80 \mathrm{de}$ & $122,92 \mathrm{~b}$ \\
N3 $(22,5)$ & $128,00 \mathrm{bcd}$ & $128,13 \mathrm{bcd}$ & $136,40 \mathrm{ab}$ & $136,47 \mathrm{ab}$ & $131,04 \mathrm{a}$ \\
\hline Rerata & $119,23 \mathrm{~b}$ & $121,48 \mathrm{~b}$ & $126,97 \mathrm{a}$ & $130,52 \mathrm{a}$ & $134,33 \mathrm{a}$ \\
\hline KK $=2,76 \%$ & BNJ N $=3,81$ & BNJ D $=3,81$ & BNJ ND $=10,47$ & \\
\hline
\end{tabular}

Angka-angka pada baris dan kolom yang diikuti huruf kecil yang sama menunjukan tidak berbeda nyata menurut uji lanjut BNJ pada taraf $5 \%$. 
Tabel 5 menunjukkan bahwa interaksi pemberian pupuk NPK Grower dan Defoliasi berpengaruh nyata terhadap berat pipilan kering. Dimana interaksi perlakuan N3D3 (pupuk NPK Grower 22,5 g/tanaman dan Defoliasi semua daun di bawah tongkol) memiliki rerata berat pipilan kering tertinggi yaitu $144,80 \mathrm{~g}$, yang tidak berbeda nyata dengan kombinasi perlakuan N2D3 yaitu $136,47 \mathrm{~g}, \mathrm{~N} 3 \mathrm{D} 2$ yaitu 136,40 g dan N2D2 yaitu $134,43 \mathrm{~g}$, tetapi berbeda nyata dengan kombinasi perlakuan lainnya. Berat pipilan kering terendah terdapat pada kombinasi perlakuan N0D0 dengan berat pipilan kering yaitu $102,23 \mathrm{~g}$, yang tidak berbeda nyata dengan kombinasi perlakuan NOD1 dan NOD2 dimana berat pipilan masing-masing adalah $107,90 \mathrm{~g}$ dan $112,47 \mathrm{~g}$.

Kombinasi perlakuan N3D3 (pupuk NPK Grower 22,5 g/tanaman dan Defoliasi semua daun di bawah tongkol) memiliki berat pipilan kering tertinggi yaitu 144,80 g, hal ini diduga karena unsur hara yang terdapat pada pupuk NPK Grower dapat langsung tersedia bagi tanaman setelah diaplikasikan, sehingga tanaman dapat memenuhi nutrisi yang dibutuhkan dalam pertumbuhan generatifnya. Selain itu Defoliasi daun di bawah tongkol dapat membantu tanaman dalam mengakumulasi bahan asimilat hasil fotosintesis untuk difokuskan kepada pengisian biji sehingga meningkatkan berat pipilan kering biji jagung.

Menurut Iskandar (2010), penggunan pupuk anorganik yang berimbang dapat meningkatkan pertumbuhan dan hasil jagung serta dapat memberikan tingkat produksi jagung yang tinggi. Menurut Dwidjoseputro (1991), tanaman akan tumbuh dengan subur apabila elemen (unsur hara) yang dibutuhkan tersedia cukup dan unsur hara tersebut tersedia dalam bentuk yang dapat dierap oleh tanaman.

Peranan unsur hara fospat (P) dalam pembentukan bunga mempengaruhi pembentukan dan ukuran tongkol, karena tongkol merupakan perkembangan dari bunga betina.Hal ini didukung oleh pernyataan Marschner dalam Syafruddin (2010), bahwa untuk mendorong pembentukan bunga dan buah sangat diperlukan unsur fospat $(\mathrm{P})$.Selanjutnya ukuran tongkol sangat mempengaruhi hasil suatu tanaman.Seperti pendapat yang dikemukakan oleh Robi'in (2009), bahwa panjang dan diameter tongkol berkaitan erat dengan rendemen hasil suatu tanaman.Jika panjang tongkol rata-rata suatu taaman lebih panjang, tersebut berpeluang memiliki hasil yang lebih tinggi.Demikian pula jika diameter tongkol suatu tanaman lebih besar maka varietas tersebut memiliki rendemen hasil yang tinggi.

Tanaman yang mendapat perlakuan defoliasi daun di bawah tongkol menunjukkan peningkatan hasil.Hal ini diduga karena tanaman mampu mengakumulasi energi hasil dari fotosintesis untuk ditranslokasikan ke bagian generatif tanaman. Hal ini sejalan dengan yang dikemukakan oleh Suminarti (2000), bahwa berkurangnya jumlah daun akibat perlakuan defoliasi akan memberikan pengaruh terhadap asimilat yang dihasilkan dan selanjutnya akan berpengaruh terhadap perkembangan dan hasil suatu tanaman. Asimilat bagi tanaman merupakan salah satu sumber energi pertumbuhan dan perkembangan tanaman.

Berat pipilan kering terendah terdapat pada perlakuan kontrol (NOD0) yaitu 102,23 g. Rendahnya produksi pipilan kering ini disebabkan tanaman kekurangan hara nitrogen $(\mathrm{N})$, fospat (P), dan kalium (K) yang dibutuhkan tanaman dalam perkembangannya sehingga menghambat pertumbuhan vegetatif yaitu tinggi tanaman dan pertumbuhan generatif yaitu pengisian tongkol. Syafruddin (2013), melaporkan bahwa pemupukan di lahan kering Inceptisol Bone dengan kombinasi NPK akan diperoleh hasil biji 8,72 t/ha, jika salah satu unsur hara $(\mathrm{N}, \mathrm{P}$ atau $\mathrm{K})$ tidak diberikan akan mengalami penurunan 0,01-5,63 t/ha. Apabila tidak dipupuk nitrogen $(\mathrm{N})$ akan menurunkan hasil 5,03 t/ha, tanpa pemupukan fospat (P) menurunkan hasil 0,89 t/ha, dan tanpa pemberian kalium $(\mathrm{K})$ menurunkan hasil $\quad 0,63$ t/ha.

Unsur nitrogen $(\mathrm{N})$ sebagai pembentuk senyawa asam-asam amino dan protein untuk pertumbuhan tanaman.Fosfat (P) sangat diperlukan untuk energy pertumbuhan (ATP) termasuk pembentukan biji, sementara kalium (K) memacu translokasi hasil fotosintesis dari daun ke bagian lain tanaman dan berperan 
untuk pembentukan karbohidrat tanaman (Marschner dalam Syafruddin, 2010).

Marschner dalam Syafruddin (2010), menyatakan bahwa kalium (K) adalah unsur yang diperlukan oleh tanaman serelia sewaktu pengisisan bulir atau biji, sedangkan fospat $(\mathrm{P})$ berperan penting dalam pembentukan bunga, buah dan biji. Dengan tersedianya unsur fospat (P) dan kalium (K) yang cukup di dalam tanah maka akan berepangaruh juga terhadap proses pembentukan biji, dimana biji akan lebih bernas sehingga berpengaruh terhadap bobot pipilan jagung.

Pratikta (2013) menyatakan bahwa semakin besar fotosintat yang dipartisi atau dialokasikan ke bagian tongkol semakin besar pula penimbunan cadangan makanan yang ditranslokasikan ke biji sehingga berat biji dapat meningkat, namun sebaliknya semakin menurun fotosintat yang dipartisi atau dialokasikan ke bagian tongkol maka semakin rendah pula penimbunan cadangan makanan yang ditranslokasikan ke biji sehingga menurunkankan berat biji. Dengan perlakuan pemangkasan daun di bawah tongkol maka daun tersebut tidak lagi mengambil hasil fotosintesis sehingga hasil fotosintesis tersebut dapat lebih dioptimalkan ke pengisian biji.Hal ini sesuai dengan yang dikemukakan Bustamam (2004) bahwa $25 \%$ daun pada bagian atas memainkan peran penting dalam pengisian biji.

Menurut Dwidjoseputra (1991), asimilasi yang diproduksi oleh daun akan didistribusikan keseluruh bagian tanaman yang membutuhkannya. Keberadaan daun dapat membantu kelancaran asimilat, tetapi daun juga dapat menjadi pengguna hasil asimilat. Hal ini akan menyebabkan asimilat terbagi ke setiap bagian tanaman sehingga biji tidak terisi dengan optimal.

\section{KESIMPULAN DAN SARAN}

\section{Kesimpulan}

Berdasarkan hasil penelitian dapat disimpulkan sebagai berikut:

1. Interaksi pemberian pupuk NPK Grower dan Defoliasi memberikan pengaruh nyata terhadap perubahan berat kering biji, perubahan kadar air biji, kecepatan penumpukan bahan kering, umur panen dan berat pipilan kering. Perlakuan terbaik pada pemberian pupuk NPK Grower 22,5 g/tanaman dan Defoliasi semua daun di bawah tongkol (N3D3).

2. Pengaruh utama pemberian pupuk NPK Grower memberikan pengaruh nyata terhadap perubahan berat kering biji, perubahan kadar air biji, kecepatan penumpukan bahan kering, waktu pengisian efektif, umur panen, panjang tongkol, diameter tongkol dan berat pipilan kering. Perlakuan terbaik pada pemberian pupuk NPK Grower 22,5 g/tanaman (N3).

3. Pengaruh utama Defoliasi memberikan pengaruh nyata terhadap perubahan berat kering biji, perubahan kadar air biji, kecepatan penumpukan bahan kering, waktu pengisian efektif, umur panen, panjang tongkol, diameter tongkol dan berat pipilan kering. Perlakuan terbaik pada Defoliasi semua daun di bawah tongkol (D3).

\section{Saran}

Dari hasil penelitian, penulis menyarankan untuk melakukan penelitian lanjutan dengan pemberian dosis NPK yang lebih tinggi dan defoliasi semua daun di bawah tongkol karena hasil masih menunjukkan kemungkinan peningkatan produksi tanaman jagung.

\section{DAFTAR PUSTAKA}

Anonimus. 1995. Budidaya Jagung. Propinsi Daerah Tingkat I Sumatera Utara.

Anonimus. 2002. Inovasi Teknologi Jagung. Pusat Penelitian dan Pengembangan Tanaman Pangan.

Anonimus.2003. Kandungan Pupuk NPK Grower. Yara Internasional: Norwegia.

Anonimus.2016. Memungkinkan Indonesia Tak Lagi Impor Jagung Pada 2017. (Online: http://bisniskeuangan.kompas.com/read/2 016/06/23/215931526/memungkinkan.in donesia.tak.lagi.impor.jagung.pada.2017. Diakses pada tanggal 29 Agustus 2016).

Bustamam, Tamsil. 2004. Pengaruh Posisi Daun Jagung Pada Batang Terhadap Pengisian Dan Mutu Benih. Fakultas Pertanian, Universitas Andalas: Padang. 
Dwidjoseputro. 1991. Pengantar Fisiologi Tumbuhan. PT. Gramedia: Jakarta.

Iskandar, D. 2010. Pengaruh Dosis Pupuk N, P dan $\mathrm{K}$ Terhadap Pertumbuhan dan Produksi Tanaman Jagung Manis di Lahan Kering. (Online: http://www.iptek.net.id. Diakses pada tanggal 10 Juli 2017).

Legwaila, G. M., T. Mathowa dan E. Jotia. 2013. The Effect of Defoliation on Growth and Yield of Sorghum (Sorghum bicolor (L) Moench) Variety Segaolane. Agriculture and Biology Journal of North. America.

Pratikta D., S. Hartatik, K. A. Wijaya. 2013. Pengaruh Penambahan Pupuk NPK Terhadap Produksi Beberapa Aksesi Tanaman Jagung (Zea mays L.). Fakultas Pertanian, Universitas Jember: Jember.

Razali.2008. Respon Dua Varietas Jagung Pada Berbagai Defoliasi dan Pemberian $\mathrm{NaCl}$. Tesis Pasca Sarjana Universitas Sumatera Utara: Medan.

Robi'in. 2009. Teknik pengujian daya hasil jagung bersari bebas (komposit) di lokasi prima tani Kabupaten Probolinggo. Buletin Teknik Pertanian: Jawa Timur.

Rukmana, R. 1997. Usahatani Jagung. Kanisius: Yogyakarta.

Satriyo, T. A. 2016. Pengaruh Posisi Dan Waktu Defoliasi Daun Pada Pertumbuhan, Hasil Dan Mutu Benih Jagung (Zea mays L.) Var. Bisma. Fakultas Pertanian,Universitas Brawijaya: Malang.

Suminarti, N. E. 2000. Pengaruh Jarak Tanam dan Defoliasi Daun Terhadap Hasil Tanaman Jagung (Zea mayz L) Varietas Bisma.Habitat.

Syafruddin dan Zubachtirodin. 2010. Penggunaan pupuk NPK majemuk 2010-10 pada tanaman jagung. Prosiding Pekan Serealia Nasional: Sulawesi Selatan.

Syafruddin. 2013. Takaran Pupuk N, P, K, Dan $S$ Tanaman Jagung Pada Beberapa Jenis Tanah Di Sulawesi Selatan. Balai Penelitian Tanaman Serealia: Sulawesi Selatan 
